\title{
Balancing Competing Interests When Building Marine Energy Infrastructures: the Case of the Nord Stream Pipelines
}

\author{
David Langlet
}

The age of large-scale hydrocarbon infrastructure projects may, partly as a consequence of climate change policy, be nearing its end. However, significant projects are still being planned and executed. Natural gas is also touted as a 'bridge' between more carbon intense coal-based energy production and carbon neutral, or almost neutral, renewable energy sources. This, together with new gas production technologies could further increase the need for gas transport infrastructure, significant parts of which are likely to be sea based. ${ }^{1}$ Also, if carbon capture and storage (CCS) emerges as a large-scale climate change mitigation technology, which some see as imperative if climate change is to be tackled affectively, ${ }^{2}$ that is likely to result in demand for submarine pipelines to transport carbon dioxide to offshore injection points. ${ }^{3}$

1 Offshore is estimated to account for almost two-thirds of the world's remaining conventional natural gas resources. International Energy Agency, Offshore Energy Outlook (OECD/IEA, 2018) 16.

2 See, inter alia, European Parliament Resolution of 14 January 2014 on Implementation Report 2013: Developing and Applying Carbon Capture and Storage Technology in Europe (2013/2079(INI)); and OECD/IEA, Technology Roadmap: Carbon Capture and Storage (OECD/ IEA 2013) 5. However, there is nolack a critics of ccs. See e.g. E Rochon, 'False Hope:Why Carbon Capture and Storage Won't Save the Climate' (Greenpeace International, May 2008) <http:// www.greenpeace.org/usa/research/false-hope-why-carbon-capture/> accessed 15 June 2014. The technology is associated with many problems, not least the lack of a viable business case for its employment in most jurisdictions. On the role of ccs and bioenergy with ccs (BECCS) in scenarios that would limit warming to $1.5^{\circ} \mathrm{C}$ above pre-industrial levels, see $\mathrm{H}$ de Coninck, A Revi, M Babiker, P Bertoldi, M Buckeridge, A Cartwright, W Dong, J Ford, S Fuss, J-C Hourcade, D Ley, R Mechler, P Newman, A Revokatova, S Schultz, L Steg, and T Sugiyama, 'Strengthening and Implementing the Global Response', in V Masson-Delmotte et al (eds), Global Warming of $1.5^{\circ} \mathrm{C}$. An IPCC Special Report on the impacts of global warming of $1.5^{\circ} \mathrm{C}$ above pre-industrial levels and related global greenhouse gas emission pathways, in the 
The construction and operation of submarine pipelines engage several parts of the law of the sea. Such activities can also affect many potentially competing interests, such as the freedom of transport, the utilization of resources in and on the seabed, protection of the marine environment, and access to secure energy supplies. With transit pipelines - i.e. those pipelines that pass over the continental shelf (CS) of one or more States without entering their territorial waters - potential conflicts between interests take on additional levels of complexity since the interests pertain to different States who may be quite differently affected by the pipelines. The States can also be in very different positions as to their ability to exercise control in relation to the pipelines and thereby influence the balancing of the interests concerned. If submarine energy pipelines are to be built and operated without unnecessarily interfering with other legitimate activities and interests, and vice versa, significant levels of coordination or cooperation between the affected States is often required.

The challenge of handling constructively and sustainably the many interests potentially affected by submarine pipelines is compounded by the relative vagueness of the applicable legal regime, not least with regard to the nature and extent of the jurisdiction that may be exercised by the States concerned.

This chapter aims to discuss, from an international- and partly EU law perspective, the challenges of managing conflicting interests associated with the use of the seabed for transport purposes. To do so it uses the Nord Stream pipeline project in the Baltic Sea, one of the most complex and contentious energy transport projects in Europe, as a case study. The focus is on issues pertaining to the physical presence and operation of the pipelines in a specific location and the interests that may prompt restrictions of the laying and operation of pipelines.

After a presentation of the Nord Stream pipeline project (Section 2), the chapter discusses which framework such sea based transport projects offer to manage competing interests, both in general terms (Section 3 ) and specifically

context of strengthening the global response to the threat of climate change, sustainable development, and efforts to eradicate poverty' (2018, in press).

3 In some regions offshore storage is the only or most abundant storage option while it in other cases may be preferred for policy reasons. Intergovernmental Panel on Climate Change (IPCC), IPCC Special Report on Carbon Dioxide Capture and Storage, prepared by Working Group II of the IPCC (Cambridge University Press, Cambridge, 2005) 223, 257 and S Teir J Hetland, E Lindeberg, A Torvanger, K Buhr, T Koljonen, J Gode, K Onarheim, A Tjernshaugen, A Arasto, M Liljeberg, A Lehtili, L Kujanpaii and M Nieminen, Potential for Carbon Capture and Storage (CCS) in the Nordic Region (VTT Research Note 2556, 2010) 73. 
in the case of Nord Stream (Section 4). The chapter ends with some concluding remarks (Section 5).

The Nord Stream project has been highly contentious and much debated. This has partly been due to the environmental risks associated with a large energy project being carried out in a unique and fragile marine area which is already subject to very high human pressures, e.g. in the form of eutrophying emissions and quite intense shipping activities. To a large extent, the debate has also been influenced by the mounting political tensions between Russia and several other European countries affected by the project.

The concerns raised by affected States vary from direct physical impacts on the environment or marine security, over economic implications of a sea-based gas transport route, to issues related to national security. ${ }^{4}$ While acknowledging that this inevitably affected the political context in which the relevant legal provisions where construed and applied the main emphasis is here on the applicable law and on issues that may be of relevance also beyond the specific region and project.

Before engaging with the legal framework, the Nord Stream project as such will be introduced.

\subsection{Background, Facts and Figures}

The Nord Stream project in its current form comprises two 1,224 kilometres long parallel gas pipelines with the combined capacity to transport 55 billion cubic meters $(\mathrm{bcm})$ of natural gas from Russia to Germany annually. The submarine pipelines originate near Vyborg in Russia, then pass through the exclusive economic zone (EEZ) and over the CS of Finland and Sweden, before entering the EEZ but also the territorial waters of Denmark, and finally landing in Lubmin, near Greifswald, in Germany. ${ }^{5}$ The first of the two pipelines became operational in 2011, the second one about a year later. In 2017, the pipeline system

4 On the various objections raised and contentions associated with the project see B Solum Whist, 'Nord Stream: Not Just a Pipeline' Fni Report 15/2008 (2008) and D Langlet 'Nord Stream, the Environment and the Law: Disentangling a Multijurisdictional Energy Project' (2014) 59 ScStL 179.

5 On the notions 'exclusive economic zone' and 'continental shelf', see section 3.2. 
operated at 93 per cent of its design capacity, delivering 51 billion cubic metres (bcm) of natural gas. ${ }^{6}$

Initial feasibility studies of different routing options were carried out in the late 1990s by North Transgas, a company whose major owners were the Russian OAO Gazprom (Gazprom) and the Finnish Fortum Oil and Gas Oy (Fortum). They found a submarine pipeline solution, similar to that eventually built, to be the most feasible option for connecting Russia's natural gas fields with the central European market. ${ }^{7}$

The pipelines were eventually built and are now operated by Nord Stream AG, a company founded in 2005 and currently owned by Gazprom, with $5^{1}$ per cent of the shares, Wintershall Holding GmbH (a BASF subsidiary) and PEG Infrastruktur AG (an E.ON Beteiligungen subsidiary) with 15.5 per cent each; and N.V. Nederlandse Gasunie and ENGIE (formerly GDF SUEZ) with 9 per cent each. ${ }^{8}$ Nord Stream AG is based in Zug, Switzerland, where also the control centre, from which the pipelines are monitored and operated, is situated. ${ }^{9}$ Nord Stream AG is thus to be regarded as a national of Switzerland and subject to Swiss jurisdiction in accordance with the nationality principle. ${ }^{10}$

\section{2 $\quad$ Purposes and Developments}

While the purpose of the Nord Stream pipeline system is to transport gas from Russia to central and Western Europe the project is also very much about avoiding transporting gas via established land-based routes, thereby reducing the control of transit States, and completely avoiding certain States becoming transit States. As Nord Stream AG has itself explained, the Nord Stream pipeline system offers a natural gas connection 'free from non-technical risks

6 'Nord Stream Reaches Average Utilisation of 93\% in 2017-51 bcm delivered to the European Union' (Nord Stream, press release 16 January 2018) < https://www.nord-stream.com/ press-info/press-releases/nord-stream-reaches-average-utilisation-of-93-in-2017-51-bcm -delivered-to-the-european-union-500/> accessed 23 June 2019.

7 T Koivurova and I Pölönen, 'Transboundary Environmental Impact Assessment in the Case of the Baltic Sea Gas Pipeline' (2010) 25 IJMCL 151, 156.

8 'Who We Are' < www.nord-stream.com/about-us/> accessed 17 August 2016. The company was originally called 'North European Gas Pipeline Company' and had a slightly different ownership. 'Nord Stream Environmental Impact Assessment Documentation for Consultation under the Espoo Convention', Nord Stream Espoo Report, February 2009, Volume II: Chapter 1-8, 21.

9 'The Nord Stream Pipeline Project', Fact Sheet, February 2013.

10 On this matter, see further D Langlet, 'Transboundary Transit Pipelines: Reflections on the Balancing of Rights and Interests in Light of the Nord Stream Project' (2014) 63 ICLQ 977,980 . 
and free of interference of a commercial or non-commercial nature by third parties."11

As has been discussed elsewhere, Nord Stream has met with much opposition, not least from States such as Poland, which view it as a way to circumvent them as transit States. ${ }^{12}$ However, this dimension of the Nord stream project is only very indirectly linked to competing uses of the seabed and will not be further discussed here. ${ }^{13}$

In 2015 Gazprom, BASF, E.ON, ENGIE, OMV and Royal Dutch Shell signed a Shareholders' Agreement on implementation of a 'Nord Stream 2' pipeline project to be developed by a new company. ${ }^{14}$ Like the original Nord Stream, the Nord Stream 2 project comprises the construction of two offshore pipelines with an aggregate annual capacity of $55 \mathrm{bcm}$ of gas to be transported from Russia to Germany through the Baltic Sea, largely along the same route as the two existing pipelines. The new company is, like Nord Stream AG, established in Switzerland, and continues the preparatory and planning activities initiated by Nord Stream AG.

In August 2016 the consortium behind Nord Stream 2 crumbled after a decision by the Polish anti-trust office not to approve the notification in Poland of a joint venture to construct and operate the new pipelines. The approval for a Polish joint venture was needed despite the planned pipelines not entering Polish waters because of the EU-based partners in the consortium being active in Poland. The notification was declined with reference to Nord Stream 2 restricting competition in gas supplies..$^{15}$ This lead to the new company, Nord

11 'Nord Stream Extension Project Information Document (PID)', March 2013, Document No. N-GE-PER-REP-000-PID00000-A, 15.

12 The then Polish defence minister Sikorski even said in 2006 that the project echoed the 1939 Molotov-Ribbentrop Pact (in which the territories of several European countries, among them Poland, were divided into Nazi-German and Soviet spheres of influence just before the outbreak of wwII), Nord Stream 'a waste of money' says Poland (EURACTIV, 11 January 2010, updated 31 August 2011) <https://www.euractiv.com/section/centraleurope/news/nord-stream-a-waste-of-money-says-poland/> accessed 28 May 2019.

13 See instead Langlet (n 4$)$ and Solum Whist (n 4).

14 Gazprom export, 'Nord Stream 2' at <http://www.gazpromexport.ru/en/projects/5/> accessed 28 May 2019.

15 A Rettman, 'Russia to build Nord Stream 2 despite Polish objection' (Euroserver, 22 August 2016) <https://euobserver.com/economic/134694> and 'Nord Stream 2 partners withdraw amid Poland pressure' (Financial Times, 12 August 2016) $<\mathrm{http}$ ://www .ft.com/fastft/2016/08/12/nord-stream-2-partners-withdraw-amid-poland-pressure/> both accessed 19 May 2019. 
Stream 2 AG, being wholly owned by Gazprom but financing agreements for the project have been signed with ENGIE, OMV, Shell, Uniper and Wintershall. ${ }^{16}$

The transit States Finland and Sweden granted permission for laying of the new pipelines in April and June 2018, respectively. ${ }^{17}$ As of June 2019, the third transit State, Denmark, had yet to make a final decision on Nord Stream 2 AG's permit application. The legal developments in Denmark regarding Nord Stream 2 are further discussed in Section 4 below.

\subsection{Legal Status}

As concluded above, both Nord Stream AG and Nord Stream 2 AG (in the following referred to collectively as 'Nord Stream' when no distinction is necessary) are Swiss companies and are with respect to the application of international law to be regarded as nationals of Switzerland and subject to Swiss jurisdiction. ${ }^{18}$ As a consequence of State sovereignty and according to the maxim pacta tertiis - the meaning of which is that no obligations can follow from an international agreement for non-parties to such agreement without the consent of the non-party in question - any obligation imposed on Nord Stream should be compatible with the legal position of Switzerland under international law. ${ }^{19}$ Switzerland became a party to the United Nations Convention on the Law of the Sea (UNCLOS) ${ }^{20}$ in May 2009, just a few months before Denmark, Finland and Sweden decided on Nord Stream AG's permit applications regarding routes on their respective CS. However, Switzerland is not a member of the European Union (EU) and hence not subject to EU law obligations. Customary international law and international agreements to which the EU is party, such as UNCLOs, have an elevated position in the EU legal system. ${ }^{21}$ But this does not rule out the possibility of conflicts with

16 Nord Stream 2, 'Shareholder and Financial Investors' at <https://www.nord-stream2 .com/company/shareholder-and-financial-investors/> accessed 28 May 2019.

17 'Nord Stream 2 Receives Full Set of Permits in Finland' (Nord Stream 2, press release, 12 April 2018) at < https://www.nord-stream2.com/media-info/news-events/nord-stream -2-receives-full-set-of-permits-in-finland-92/> accessed 28 May 2019; 'Decision on application from Nord Stream 2 AG' (Swedish government, press release, 7 June 2018) at $<$ https:// www.government.se/press-releases/2018/06/decision-on-application-from-nord-stream -2 -ag/> accessed 28 May 2019.

18 See father Langlet (n 10) 980.

19 This customary principle has been codified in the Vienna Convention on the Law of Treaties (Vienna, 23 May 1969) 1155 UNTS 331 arts 34-36.

20 UN Convention on the Law of the Sea (Montego Bay, 10 December 1982) (UNCLOS).

21 For a succinct account of the relationship between EU law and public international law, particularly in the field of environmental protection, see D Langlet and S Mahmoudi, $E U$ Environmental Law and Policy (Oxford University Press 2016) 124 et seq. 
respect to the application of EU standards to non-EU nationals, such as Nord Stream AG. ${ }^{22}$

However, the potential imposition of an obligation on Nord Stream, as a private legal subject, that is not consistent with international law, would not be a violation of any right of Nord Stream's, but rather a transgression of Switzerland's rights under international law and could justify the exercise by Switzerland of diplomatic protection (ius protectionis) with respect to the company. ${ }^{23}$

\subsection{Mapping of Interests}

There are two sets of interests, widely construed, that are directly linked to the pipelines, their routing and operation. One is the general interest of the concerned States to exercise authority, understood as legislative and executive jurisdiction, over activities on their CS and in their EEZ which may somehow affect them. Potential conflicts are thus a matter of competing claims of jurisdiction in relation to the pipelines and their operation.

The second set of interests covers substantive interests, such as protection of the environment, unimpeded access to natural resources in or on the seabed, and the freedom to lay and operate pipelines for economic or other purposes. These sets of interests are functionally linked since whoever gets to exercise legal authority in a certain case to some extent thereby becomes the arbiter between competing substantive interests. At the same time, this competence is contingent on the specific circumstances since the right to exercise authority, understood as competence to regulate and enforce rules and decisions, over a certain area (i.e. maritime zone) varies depending on what substantive interests are at issue. Although a distinction between jurisdictional interests and substantive interests may have an analytical value they are, from a legal perspective, often indissociably linked.

22 For a comprehensive analysis of the relationship between EU law and international law in the related field of maritime safety, see H Ringbom, The EU Maritime Safety Policy and International Law (Brill - Nijhoff, 2008).

23 On diplomatic protection, see further The International Law Commission, ILC's Draft Articles on Diplomatic Protection', Official Records of the General Assembly, Sixty-first Session, Supplement No. $10(\mathrm{~A} / 61 / 10)$ art 1. 


\subsection{General Rules on Jurisdiction}

One of the main purposes of UNCLOS is clearly to allocate competencies in relation to areas and activities between different actors, primarily States acting in different capacities such as flag State, coastal State, or port State. This chapter focuses on those rules most directly relevant to the use of the seabed on the CS for energy purposes, particularly the laying and operation of submarine pipelines. $^{24}$

The maritime zones of interest here are the EEZ and the CS, and to a lesser extent the high seas. The territorial sea is in this respect less interesting since in this zone the coastal State has virtually unrestricted jurisdiction with respect to energy infrastructure. ${ }^{25}$ There is thus little room for competing claims regarding the construction and operation of, for example, pipelines in this area.

While there is no high seas - i.e. parts of the sea not included in the EEZ, the territorial sea, or the internal waters of a State ${ }^{26}$ - in the Baltic Sea, it is still relevant to note that the so-called freedom of the high seas comprises not only a freedom of navigation and of overflight but also, inter alia, the freedom to lay submarine pipelines and cables. ${ }^{27}$ And, as we shall see, the freedoms of the high seas apply also, although subject to additional restrictions, in the EEz.

24 For a general presentation of the jurisdictional system set out in UNCLOS, see e.g. D R Rothwell, A G Oude Elferink, K N Scott, and T Stephens (eds), The Oxford Handbook of the Law of the Sea (Oxford University Press 2015); and Y Tanaka, The International Law of the Sea (2nd edn, Cambridge University Press 2015).

25 Where geography allows, the coastal State may claim a territorial sea that stretches $12 \mathrm{~nm}$ from the baseline. Here the coastal State in most respects exercises sovereignty in a way similar to what applies on its land territory. UNCLOS (n 20) arts 2-3. However, as the Danish example shows, limitations on the ability to exercise this right can follow from domestic law. Until 2017 Danish law lacked a provision enabling the restriction of the laying of pipelines within the territorial waters based on for example foreign policy considerations. In December that year, an executive order was issued to the effect that approval by the Foreign Minister is required for the granting of a permit for the laying of pipelines within the Danish territorial sea. Bekendtgørelse om visse rørledningsanlæg på søterritoriet og kontinentalsoklen, BEK nr $15^{20}$ af 15/12/2017 (Executive order on certain pipelines in the territorial sea and on the continental shelf). Although drafted so as to be of general applicability, this legislative action was clearly aimed at the ongoing Nord Stream 2 process.

26 UnCLOS (n 20), art 86. To be exact, the archipelagic waters of an archipelagic State are also not part of the high seas.

27 UNCLOS (n 20) art 87(1). Additional freedoms are the freedom to construct artificial islands and other installations permitted under international law, subject to UNCLOS (n 20) Part VI; the freedom of fishing, subject to the conditions laid down in UNCLOS Part VII, section 2; and the freedom of scientific research subject to UNCLOS Parts VI and XIII. 
Pipelines are normally laid on the seabed, which, at least within 200 nautical miles from the baseline, ${ }^{28}$ forms part of the CS. ${ }^{29}$ The CS does not have to be claimed by the coastal State but exists ipso facto. ${ }^{30}$ The Baltic Sea is not wide enough for there to be any seabed beyond the CS. Also beyond this region energy transport infrastructure is for practical reasons mostly restricted to the CS.

Without affecting the legal status of the superjacent waters, the coastal State exercises sovereign rights over the CS for the purpose of exploring it and exploiting its natural resources. ${ }^{31}$ This means, inter alia, that all extraction of oil and gas, as well as utilization of living organisms belonging to sedentary species, ${ }^{32}$ are the exclusive prerogatives of the coastal State.

In the Baltic Sea there is no CS not covered by a water column constituting the EEZ of the pertinent coastal State. Unlike the CS, the EEZ has to be claimed by the coastal State but all such States affected by the laying of the Nord Stream pipelines have, like most coastal States, claimed an EEZ.

In many respects the legal regime for the EEZ supplements that for the CS. ${ }^{33}$ In the EEz the coastal State enjoys sovereign rights for the purpose of exploring and exploiting, conserving and managing the living as well as non-living natural resources. This applies to the waters superjacent to the seabed as well as to the seabed and its subsoil. The coastal State also has sovereign rights with regard to other activities for the economic exploration and exploitation of the zone. ${ }^{34}$ Furthermore, the coastal State has jurisdiction, as provided for in relevant provisions of UNCLOS, with regard to the protection and preservation of the marine environment, marine scientific research, and the establishment and use of artificial islands, installations and structures. ${ }^{35}$ Pipelines are not, however, installations or structures in this regard but are subject to their own regulatory structure. ${ }^{36}$

28 Baselines are defined in UNCLOS (n 20), arts 5 and 7.

$29 \operatorname{UNCLOS}(\mathrm{n} 20) \operatorname{art} 76(1)$.

$30 \quad \mathrm{UNCLOS}(\mathrm{n} 20) \operatorname{art} 77(3)$.

31 UNCLOS (n 20) art 78.

32 Sedentary species are those organisms which, at the harvestable stage, either are immobile on or under the seabed or are unable to move except in constant physical contact with the seabed or the subsoil. UNCLOS (n 20) art 77.

33 The relationship between the two regimes is discussed in section 4.3.

34 UNCLOS (n 20) art 56(1)(a).

35 UNCLOS (n 20) art 56(1)(b).

36 R Lagoni, 'Pipelines' in R Wolfrum (ed), Max Planck Encyclopedia of Public International Law (e-resource, Oxford University Press 2008, updated April 2011) para 10. 


\subsection{Jurisdiction with Respect to Pipelines}

Turning now to the specific legal conditions applying to submarine pipelines it should first be noted that the regulation of pipelines in UNCLOS is characterized by a delicate, and at times rather vague, balancing of the interests of different actors, primarily coastal States and those wanting to lay and operate pipelines, and between objectives, including protection of the marine environment and the right to lay and operate pipelines as part of the freedom of the seas. However, this is far from specific to pipelines. Rather, UNCLOS is replete with provisions that balance potentially competing interests. ${ }^{37}$

As a point of departure, all States, and indirectly their citizens, ${ }^{38}$ enjoy, with some exceptions, the freedom of the high seas in the EEz. This freedom comprises, inter alia, freedom of navigation and overflight and of the laying of submarine cables and pipelines, but also other internationally lawful uses of the sea related to these freedoms, such as those associated with the operation of ships, aircraft and submarine cables and pipelines. The activities carried out under this freedom must be compatible with other relevant provisions of UNCLOS. ${ }^{39}$ Also, with respect to the seabed and subsoil the coastal State's sovereign rights and jurisdiction are to be exercised in accordance with Part VI of UNCLOS concerning the rules on the CS.

According to UNCLOS Part VI, all States are entitled to lay submarine cables and pipelines on the CS. However, whereas the coastal State may not otherwise impede the laying or maintenance of such cables or pipelines on the CS it has a right to take 'reasonable measures for the exploration of the continental shelf, the exploitation of its natural resources and the prevention, reduction and control of pollution from pipelines'. 40 This also means that UNCLOS does not allow for restrictions on the laying or operation of submarine pipelines for other reasons, such as security or energy policy considerations. ${ }^{41}$

37 The most explicit reference to such weighing up of interests is perhaps found in art 59 but it is also implicit in many other provisions or combinations of provisions.

38 The freedom pertains to States, not individuals. But in practice the activities covered by the freedom of the high seas are overwhelmingly exercised by private parties. W Wiese, Grenzüberschreitende Landrohrleitungen und Seeverlegte Rohrleitungen im Völkerrecht (Duncker \& Humblot GmbH 1997) 210.

39 UNCLOS (n 20) art 58(1). When exercising these freedoms in the EEZ other States must also comply with the laws and regulations adopted by the coastal State in accordance with the provisions of UNCLOS and other rules of international law in so far as they are not incompatible with the provisions on the EEZ in UNCLOS. ibid art $58(3)$.

$40 \quad$ UNCLOS (n 20) art 79(1) and (2).

41 Koivurova and Pölönen (7) 179. However, in the Nord Stream case 'the security of energy supply' was listed in the Finnish permit decision as one of the impacts of the project 
As regards protection of the marine environment, coastal States not only have a right to control the laying of pipelines on their CS. They are also, like other States, under a general obligation to take 'all measures necessary to ensure that activities under their jurisdiction or control are so conducted as not to cause damage by pollution to other States and their environment'. ${ }^{42}$ They are also subject to a more specific requirement to adopt laws and regulations to prevent, reduce and control pollution of the marine environment arising from or in connection with seabed activities under their jurisdiction. ${ }^{43}$ To the extent that for example the design or routing of a pipeline is subject to the coastal State's control, it thus has a corresponding obligation to take reasonable measures to prevent the pipeline from causing pollution.

Whereas the requirement that measures must be 'reasonable' is inherently vague it is clear that the assessment by the coastal State of what is reasonable must be carried out in good faith. ${ }^{44}$ However, nothing precludes in principle the imposition by the coastal State of conditions that make the laying of a pipeline economically or technically unviable as long as those conditions are genuinely prompted by and needed for the protection of one of the interests recognized by UNCLOS. Whether these conditions are met can be a contentious matter but anyone seeking to legally challenge an allegedly unjustified restriction imposed by the coastal State will have the burden of showing at least a prima facie breach of that State's international obligations.

Although it is not for the coastal State to question the motive or need for a pipeline, it is wholly conceivable that the importance of the pipeline to other States than the coastal State could become a factor in the assessment of whether a measure by the coastal State is reasonable. ${ }^{45}$

that were to be weighed up in the assessment. 'Consent to Exploit Finland's Exclusive Economic Zone' (5 November 2009) 678/601/2009 (Unofficial translation provided by the Ministry of Employment and the Economy) 28. But from this cannot be inferred that the Finnish government was of the view that a negative impact in this regard would in itself justify a rejection of the application. In the end, no negative impact on Finnish security of energy supply was identified.

UNCLOS (n 20) art 194(2). There are also more specific obligations imposed upon coastal States in this regard both by UNCLOS and numerous regional conventions. See e.g., UNCLOS art 208 and the Convention on the Protection of the Marine Environment of the Baltic Sea Area, 'Helsinki Convention' (Helsinki, 9 April 1992) 1507 UnTs 167.

43 UnCLOS (n 20) art 208.

44 This follows generally from the Vienna Convention on the Law of Treaties (n 19) art 26, but also from UNCLOS (n 20) art 300.

45 For a more extensive analysis of the meaning of 'reasonable' in this context, see Langlet (n 10) $990-3$. 
Another important right also pertains to the coastal State: the delineation of the course for the laying of submarine pipelines on the CS is subject to its consent. ${ }^{46}$ It is thus not the laying as such that requires consent but the pipeline's delineation. However, for practical purposes the delineation and the laying are indissociable since any laying entails a particular delineation. This consent requirement also gives the coastal State reason to put in place a permit procedure which can also be used to decide on reasonable measures to protect legally recognized interests.

Importantly, the waters above the CS remain governed solely by the EEZ-regime. This means that structures above the seabed, such as the maintenance platform initially planned for the original Nord Stream pipelines, are subject to additional jurisdictional rights of the coastal State. Under the regime for the EEZ the coastal State has, as previously noted, sovereign rights inter alia with regard to all activities for the economic exploration and exploitation of the zone and, subject to other provisions in UNCLOS, jurisdiction with regard to the establishment and use of installations and structures.

In sum, a coastal State has rather far-reaching authority to influence and restrict the laying of submarine pipelines on its CS. However, the drafters of UNCLOS clearly did not intend to grant the coastal State a carte blanche for prohibiting pipelines on its CS. But the vagueness of the restrictions imposed on the coastal State in this regard does invite discrepant interpretations and potentially conflict.

In the Nord Stream case, no affected State has legally challenged any decision regarding the laying, delineation, or operation of the pipelines on the CS and the Nord Stream companies have only appealed one decision by a national authority. This is not too surprising considering that all affected States granted their consent to the two existing pipelines, although with various conditions, ${ }^{47}$ and that two out of three transit states have also consented to Nord Stream 2. But as will be seen in the following section this does not mean that the Nord Stream project was not affected by different assessments or competing views on the weighing up of interests, sometimes resulting in legal action being taken.

$46 \quad$ UNCLOS (n 2o) art 79(3).

47 On some of these conditions, see section 5 . For a more extensive analysis, see Langlet ( $\left.n_{4}\right)$. 


\section{The Impact and Handling of Competing Interests in the Nord Stream Case}

The legal authority to regulate the laying and operation of submarine pipelines on the CS, and thereby act as arbiter between different competing interests, is affected by a delicate balance between on the one hand the coastal State's interest to control activities on its CS, and the related obligation to take measures for the protection of the marine environment, and on the other hand the interest of transport and communication as manifested in the right to lay submarine cables and pipelines on the CS of any State.

The limited and rather vaguely defined right of the coastal State to restrict pipeline operations is potentially problematic for a number of reasons. One fairly obvious risk is that coastal States will be tempted to circumvent the restrictions on their right to regulate pipelines by using a legitimate objective, such as protection of the marine environment, as a pretext for pursuing objectives not recognised by UNCLOS. The suspicion that coastal States will act in this manner could also make (prospective) pipeline operators, and potentially their home States, sceptical towards the environmental concerns raised by coastal States. On the other hand, legally extraneous factors, such as political pressure felt by small countries when big States invest heavily in the pursuance of a large energy project, could conceivably lead to less than diligent assessment and consideration of effects to the marine environment. So, to what extent did these risks materialize in the Nord Stream case? And was the legal framework appropriate for managing conflicting interests in a constructive manner?

Highly relevant in terms of potential conflicts is that applications by Nord Stream AG to survey the seabed in preparation for a potential routing through Estonian waters were rejected by the Estonian government in 2007 and 2012. ${ }^{48}$ Since surveying the seabed is an indispensable part of the planning and

48 'The Government did not agree to issue a permit for the survey application' (Government Communication Unit, 20 September 2007) < valitsus.ee/et/uudised/pressiteated/ keskkonnaministeerium/13572> accessed 15 August 2013; and 'Cabinet meeting decides to deny Nord Stream AG's request to conduct marine investigations in Estonia's exclusive economic zone' (Government Communication Unit, 6 December 2012) <http://valitsus.ee/ et/uudised/pressiteated/majandus-ja-kommunikatsiooniministeerium/73717 $>$ accessed 15 August 2013. On the Estonian opposition to the Nord Stream project, see Solum Whist (n 4) 71; R Götz, 'The Nord Stream Pipeline: The Energy Policy Background' (2009) 52 GYIL 233; and S Vinogradov, 'Challenges of Nord Stream: Streamlining International Legal Frameworks and Regimes for Submarine Pipelines' (2009) $5^{2}$ GYIL 30. 
construction of a submarine pipeline this meant that the Estonian CS was unavailable to Nord Stream AG. ${ }^{49}$ The primary reasons cited by Estonia were not environmental but national interests in the EEZ and that surveys would give information about Estonia's natural resources and their possible use. ${ }^{50}$ Estonia seemed to view the intended surveys as marine scientific research in the terminology of UNCLOS and thereby subject to coastal State consent. ${ }^{51}$ Although that classification, and thereby the coastal State's right to restrict surveys on this ground, could be disputed it is nonetheless clear that the surveys, which were to involve drilling in the seabed, did require consent by the coastal State. ${ }^{52}$ It is namely the exclusive prerogative of the coastal State to authorize drilling in the seabed and there are no circumstances in which it is explicitly required to give such consent. ${ }^{53}$ There would thus hardly have been any prospect for successfully challenging the Estonian decision, had any affected actor desired to do so.

A somewhat similar development was seen with respect to the maintenance platform that Nord Stream initially planned to build in the Swedish EEz. In this case no application was ever rejected but Nord Stream withdrew the platform application in 2008 and opted instead for another technical maintenance solution, based on deployment of so-called intelligent pipeline inspection gauges, or 'pigs'. The decision to withdraw the application, which according to the company was made possible by technical progress, came in response to a very critical debate in Sweden regarding perceived environmental, fisheries and security concerns relating to the platform and to some extent the pipelines as such. ${ }^{54}$ Considering that the platform would have been governed by

49 The main purpose of such surveys is to identify a suitable pipeline route, i.e. a route that will minimize the risk for harm to the future pipeline, and indirectly harm to the environment and human activities in the vicinity of the pipeline, and avoid conflicts with other uses of the seabed. R Lagoni, 'Cable and Pipeline Surveys at Sea', in HP Hestermeyer and others (eds), Coexistence, Cooperation and Solidarity: Liber Amicorum Rüdiger Wolfrum, Vol. 1 (Brill 2012) 933, 933 .

$5^{0} \quad$ The Government did not agree ...' (n 48).

51 On the legal preconditions for marine scientific research, see UnCLos (n 20) Part XIII; M Gorina Ysern, An International Regime for Marine Scientific Research (Brill-Nijhoff 2004), and more specifically in relation to pipeline surveys, Langlet (n 10) 986.

52 On the role and legal status of seabed surveys in preparation for the laying of submarine pipelines, see Langlet (n 10) 986; Vinogradov (n 49) 284; and S Wolf, Unterseeische Rohrleitungen und Meeresumweltschutz (Springer 2011) 86.

53 UNCLOS (n 20) art 81.

54 'Maintenance of Nord Stream Pipelines Feasible without a Service Platform' (Press Release, 8 April 2008) < http://www.nord-stream.com/press-info/press-releases/maintenance-of -nord-stream-pipelines-feasible-without-a-service-platform-130/> accessed 19 May 2019. 
the EEZ regime, it is fairly clear that Nord Stream could not have been successful in legally challenging a potential rejection of its application by the Swedish authorities.

Whereas no part of the Nord Stream project has been challenged directly under international law, there has been some appeals to domestic courts and other appellate bodies, the most significant of which perhaps being an appeal by Nord Stream 2 AG of a decision by the Danish Energy Agency. In April 2017 the company behind Nord Stream 2 submitted an application for the laying of two pipelines through the Danish territorial sea South of the island of Bornholm, in parallel with the two existing Nord Stream pipelines. In August 2018 it submitted another application, this time for an alternative route North of Bornholm that would pass through the Danish EEz outside of territorial waters. ${ }^{55}$ The option of laying the pipelines beyond the territorial sea south of Bornholm was not available due to the relevant area being subject to a legal dispute between Denmark and Poland. However, in November 2018 the two countries reached an agreement, subject to ratification, on the delimitation of their respective EEZ and CS in the area south of Bornholm, thereby making it possible for Denmark to authorise the laying of pipelines on the CS in this area. ${ }^{56}$ In early 2019 Nord Stream 2 AG was informed that it would be required to submit an application, including an environmental impact assessment, for such a routing so as to enable the Danish authorities to select the routing with the least negative impact on the marine environment and marine safety. Once a formal decision to request the assessment of a new route had been made in March 2019, Nord Stream 2 AG appealed to the Danish Energy Board of Appeal, arguing inter alia that the Danish Energy Agency lacked the right to request the full investigation of a new routing option at such a late stage in the process. ${ }^{57}$ However, despite its appeal, the company submitted an application, with an attendant impact assessment, for a southern route through the Danish EEZ in April the same year. ${ }^{58}$ At the same time, it argued in its appeal that any

55 Nord Stream 2, 'Permitting Process in Denmark' < https://www.nord-stream2.com/ permitting-denmark/danish-permitting-process/> accessed 26 June 2019.

56 'Polen og Danmark indgår aftale om den maritime grænse i Østersøen' (Poland and Denmark reach agreement on maritime delimitation in the Baltic Sea), Ministry of foreign affairs of Denmark, press statement, 1 November 2018.

57 Klage over Energistyrelsens afgørelse af 26. marts 2019 om en sydlig rute på kontinentalsoklen (Appeal of the decision of 26 March 2019 by the Danish Energy Agency concerning a southern route on the continental shelf), 17 April 2019, Doc no 21148344.1.

$5^{8}$ Reportedly, the companies view was that it was 'forced to submit this third application as a mitigation measure'. Reuters, 'Nord Stream 2 says Denmark tries to delay pipeline as it seeks third route option', 15 April 2019, < https://www.reuters.com/article/us-gazprom 
environmental advantage of such a route would be too marginal to justify the additional costs and delays suffered by the company. At the time of writing, the Danish Energy Board of Appeal has not decided on the matter. Depending on the outcome this could become a case in which environmental reasons have been used, and accepted by a domestic legal system, to at least partly further other interests, namely to delay the need for making a final decision on what has become a highly controversial issue in Denmark. A challenging circumstance for Denmark is of course that is has already found the laying of gas pipelines, i.e. the two existing Nord Stream pipelines, through its territorial sea south of Bornholm not to entail significant environmental harm.

During the process for the original Nord Stream pipelines the Danish permit was appealed by an Estonian NGO claiming, inter alia, that the pipelines would harm the integrity of internationally protected areas, such as Natura 2000 sites, ${ }^{59}$ and areas protected under the Ramsar Convention. ${ }^{60}$ However, the Energy Board of Appeal found neither evidence nor probability of such harm and upheld the original permit decision. ${ }^{61}$

The construction permit for the Finnish part of the original Nord Stream pipelines was appealed by Estonian environmental non-governmental organizations (NGOS). They asserted, inter alia, that the permit was based on insufficient and incorrect information and called for an independent expert assessment. They were granted standing but the permit was upheld by the Finnish Supreme Administrative Court. ${ }^{62}$

Neither of these are internationally authoritative assessments of the concerned States' application of international and EU law obligations pertaining to protection of the environment. They do, however, speak against the idea that the coastal States in question to some extent disregarded their obligations with respect to the marine environment as a result of the political context. The same can be said for the fact that the Swedish authorities rejected the documentation initially provided by Nord Stream AG and required a detailed

-nordstream-2-denmark/nord-stream-2-says-denmark-tries-to-delay-pipeline-as-it -seeks-third-route-option-idUSKCN1RR15F $>$ accessed 26 June 2019.

59 On the Natura 2000 network of protected natural areas and its regulation in EU law, see Langlet and Mahmoudi (n 21) 356.

6o Convention on Wetlands of International Importance Especially as Waterfowl Habitat (Ramsar, 2 February 1971) 996 UnTS 245 (Ramsar Convention).

61 Decision by the Energy Board of Appeal (Energiklagenævnet), 31 May 2010, Eksp.nr.: 49725 (translation).

62 Decision by the Supreme Administrative Court, 22 June 2011, No 4324/1/10. 
description of alternative routes for the entire route of the pipelines as well as a no-action alternative. ${ }^{63}$

Environmental concerns raised by coastal States have also resulted in significant amendments compared to the original plans. The initially proposed routing of the existing pipelines was changed on several occasions, including during the Finnish, the Swedish and the Danish assessments, as a result of concerns raised in consultations. Adjustments to the routing were primarily prompted by the prevalence of dumped munitions and mines and the proximity of the planned pipeline to protected areas, notably those designated as Natura 2000. ${ }^{64}$

That rules on the protection of Natura 2000 sites, based as they are in EU law, were applied so directly to the project may give rise to some questions, considering that the applicant is a Swiss company. However, since 'pollution of the marine environment' is quite broadly defined in UNCLOS, ${ }^{65}$ measures for the protection of sites of particular natural value, or sites that are important for the preservation of particular species, should be consistent with the right to take reasonable measures to prevent pollution from pipelines. The obligation to take all measures necessary to prevent, reduce and control pollution of the marine environment has even been construed to encompass 'measures focussed primarily on conservation and the preservation of ecosystems.' ${ }^{\prime} 6$ There are hence good grounds for seeing most obligations stemming from EU law on Natura 2000, as well as other nature protection provisions, as consistent with UNCLOS, as long as they are not applied arbitrarily or without a scientific basis. ${ }^{67}$ Nord Stream AG has also accepted modifications to the proposed

63 Request for a supplement to the application for a permit for a pipeline system under the Continental Shelf Act (1966:314) and the application for a permit to build and use a service platform under the Swedish Exclusive Economic Zone Act (1992:1140), 12 February 2008, $\mathrm{M} 2007 / 5568 / \mathrm{F} / \mathrm{M}$.

64 See, e.g., Bundesamt für Seeschiffahrt und Hydrographie, Genehmigungsbescheid, 28 December 2009, 63 et seq. For a more detailed discussion about the national permit procedures and the changes prompted by them, see Langlet ( $\mathrm{n} 4)$.

65 'Pollution of the marine environment' is defined as 'the introduction by man, directly or indirectly, of substances or energy into the marine environment, including estuaries, which results or is likely to result in such deleterious effects as harm to living resources and marine life, hazards to human health, hindrance to marine activities, including fishing and other legitimate uses of the sea, impairment of quality for use of sea water and reduction of amenities.' UNCLOS (n 20) art 1(1)(4).

66 Chagos Marine Protected Area Arbitration (Mauritius v United Kingdom), Arbitral Award of 18 March 2015, para 538 .

67 However, considering the still disputed status of precaution in international law (Y Tanaka, Principles of international marine environmental law, in R Rayfuse (ed), Research Handbook on International Marine Environmental Law (Edward Elgar 2015) 31 
route based on considerations for Natura 2000 sites without raising any objections as to the legitimacy of these requirements. Nor has Russia, as the sending State and a non-EU member raised such concerns. It should also be noted that obligations to 'conserve natural habitats and biological diversity and to protect ecological processes' as well as to apply the precautionary principle, including by taking preventive measures when there is reason to assume that substances or energy introduced into the marine environment may harm living resources and marine ecosystems can be found in the Helsinki Convention to which both Russia and Switzerland are parties. ${ }^{68}$

Unlike the different economic and security dimensions of the projects, the potential environmental effects of the Nord Stream pipelines have been subject to formal impact assessment under both international and EU law. ${ }^{69}$ Notably, the project was subject to an international environmental impact assessment (EIA) in accordance with the Espoo Convention, ${ }^{70}$ which was carried out more thoroughly than the States concerned were obliged to by the Convention's minimum requirements. ${ }^{71}$ Also Russia, a non-party to the Espoo Convention, agreed to apply the Convention to the extent permitted by its national legislation.

The Finnish government referred to its participation in the EIA under the Espoo Convention as its way to dispose of the obligation to cooperate that pertains to States bordering a semi-enclosed sea like the Baltic Sea. ${ }^{72}$ Such States are expected to cooperate with each other in the exercise of their rights and in the performance of their duties under UNCLOS, for example by endeavouring to coordinate the implementation of their rights and duties with respect to the protection and preservation of the marine environment. ${ }^{73}$ However, that this provision would entail a binding obligation of any level of substance

at 43) the strict version of the precautionary principle that characterises some parts of the Natura 2000 regime (Langlet and Mahmoudi, $\mathrm{n} 21,359$ ) are unlikely to be fully consistent with UNCLOS.

68 Helsinki Convention (n 42 ) arts 3 and 15.

69 See e.g. 'Nord Stream Environmental Impact Assessment (EIA) Documentation for Consultation under the Espoo Convention', Nord Stream Espoo Report: Non-Technical Summary, February 2009.

70 Convention on Environmental Impact Assessment in a Transboundary Context (Espoo, 25 February 1991) 1989 UnTs 310 (Espoo Convention).

71 Koivurova and Pölönen (n 7$) 174$.

72 'Consent to Exploit Finland's Exclusive Economic Zone' (n 41 ) 23.

73 UNCLOS (n 20) art 122. The Baltic Sea qualifies as semi-enclosed both since it is 'surrounded by two or more States and connected to another sea or the ocean by a narrow outlet' and since it consists 'entirely or primarily of the territorial seas and exclusive economic zones of two or more coastal States' ibid. 
is disputed and no conclusion to the contrary can be drawn from the Nord Stream case. ${ }^{74}$

As far as competition for space on the seabed between communication and transport installations, i.e. primarily cables and pipelines, is concerned, the Nord Stream case indicates that this need not be a major problem. Typically there are technical solutions to handle intersections between submarine pipelines and/or cables so that they can coexist, provided that the regulatory context facilitates that. ${ }^{75}$

\section{5}

\section{Conclusions}

The Nord Stream projects have affected many interests and entailed complex permit procedures involving five States and an even wider transboundary EIA. Some of the main bones of contention affecting the projects have not been directly linked to the physical presence of the pipelines on a particular stretch of the seabed, and therefore not within the primary purview of this analysis. We did, however, identify a risk of issues not recognised by UNCLOS as legitimate grounds for restricting pipeline operations nonetheless influencing decisions. This stems not least from the legal framework for the laying and operation of submarine pipelines on the CS being characterised by a level of uncertainty due to the imprecise manner in which the authority of the coastal State to regulate such activities is worded.

This has not result in any legal action under international law. Since all required permits for the existing two pipelines were eventually granted, with the exception of the one for surveying the seabed in the Estonian EEZ which was in fact not essential to the project, there was no real incentive to take issue with the result of the decision making processes.

The permit procedures of the transit States also appear generally to have been characterised by a desire to construe and apply the applicable law diligently and in good faith, despite heavy criticism based on considerations not recognized by UNCLOS being directed against the project in some of these States. ${ }^{76}$ The decision by a Danish authority to request the investigation of

74 E Franckx and M Benatar, "The "Duty" to Co-Operate for States Bordering Enclosed or Semi-Enclosed Seas' (2013) 31 Chinese (Taiwan) YBInt'lL\&Aff 66.

75 See L.O. Askheim 'Commercial arrangements and liability for crossing pipelines, power cables and telecommunication cables on the seabed', Chapter 23 of this book.

76 On this criticism, see e.g. Solum Whist (n 4) 30; and R L Larsson, 'Nord Stream, Sweden and Baltic Sea Security', Swedish Defence Research Agency (FOI), March 2007, FOI$\mathrm{R}-2251^{-S E} 35^{-7}$. 
a third routing option about two years after Nord Stream 2 AG's submission of its first application, one that essentially corresponds to a pipeline routing that has previously been approved by Denmark, gives rise to the suspicion that environmental and maritime safety concerns may here have been used for aims not recognized by UNCLOS. However, the final outcome is still unclear and there are no indications that Denmark intends to not approve any route.

That relevant international provisions overall seem to have been applied in good faith may have been facilitated by the projects being subject to an ambitious international impact assessment in accordance with the Espoo Convention, involving all the States concerned. Despite proposals to that effect, ${ }^{77}$ the EIA did not consider broader policy considerations pertaining to for example energy security and climate policy, but focused on the environmental impact of the pipelines as such. That may have helped to focus the subsequent permit procedures on the legally relevant issues, including protection of the marine environment and utilization of the resources of the seabed.

One legal issue that did come to the fore in this case was the legal significance of the need to drill in the seabed in preparation for pipeline laying. Since the coastal State can reject drilling in the CS at its discretion the need for surveys involving drilling can de facto provide coastal States with additional leverage beyond the powers granted in the provisions of UNCLOs dealing with pipelines. This does not seem to increase the legal uncertainty or the propensity to engage legal remedies. Rather, since the right exercised by the coastal State in this case is set out in absolute terms it has made the coastal State's competence somewhat easier to define.

As regards the concerns that coastal States could feel pressured not to take sufficient action for the protection of the marine environment, there is in fact much to indicate that environmental concerns played a central role in the assessments made by most coastal States. They clearly had a significant impact on the final routing of the pipelines.

Overall, the experience so far from the Nord Stream projects indicate that coastal States, including those that are merely transit States, have relatively strong instruments for influencing how pipelines are laid. With one possible exception, the fear that restricting coastal State authority to the protection of a few legitimate interests would result in excessive interpretations of those interests, or otherwise in actions that would upset the balance between competing interests have not materialized. 
Whether limiting transit State competence to reasonable measures for the protection of a few listed interests is the optimal way to regulate pipeline laying on the CS may of course be debated. Expanding that right to also include wider security or other policy considerations could, however, give such States a de facto veto over pipeline laying, something that was not intended by the drafters of UNCLOS. 